The University of Maine

\title{
DigitalCommons@UMaine
}

Earth Science Faculty Scholarship

Earth Sciences

8-1-2008

\section{Foreword to the Special Issue: Arctic Palaeoclimate and Its Extremes (APEX)}

Martin Jakobsson

Robert F. Spielhagen

Jörn Thiede

Claus Andreasen

Brenda L. Hall

University of Maine - Main, brendah@maine.edu

See next page for additional authors

Follow this and additional works at: https://digitalcommons.library.umaine.edu/ers_facpub

Part of the Earth Sciences Commons

\section{Repository Citation}

Jakobsson, Martin; Spielhagen, Robert F.; Thiede, Jörn; Andreasen, Claus; Hall, Brenda L.; Ingólfsson, Ólafur; Kjær, Kurt H.; van Kolfschoten, Thijs; Krinner, Gerhard; Long, Antony; Lunkka, Juha-Pekka; Subetto, Dmitry; and Svendsen, John Inge, "Foreword to the Special Issue: Arctic Palaeoclimate and Its Extremes (APEX)" (2008). Earth Science Faculty Scholarship. 151.

https://digitalcommons.library.umaine.edu/ers_facpub/151

This Editorial is brought to you for free and open access by DigitalCommons@UMaine. It has been accepted for inclusion in Earth Science Faculty Scholarship by an authorized administrator of DigitalCommons@UMaine. For more information, please contact

um.library.technical.services@maine.edu. 


\section{Authors}

Martin Jakobsson, Robert F. Spielhagen, Jörn Thiede, Claus Andreasen, Brenda L. Hall, Ólafur Ingólfsson, Kurt H. Kjær, Thijs van Kolfschoten, Gerhard Krinner, Antony Long, Juha-Pekka Lunkka, Dmitry Subetto, and John Inge Svendsen 


\title{
Foreword to the special issue: Arctic Palaeoclimate and Its Extremes (APEX)
}

\author{
Martin Jakobsson ${ }^{1}$, Robert F. Spielhagen ${ }^{2}$, Jörn Thiede ${ }^{3}$, Claus Andreasen ${ }^{4}$, Brenda Hall ${ }^{5}$, Ólafur Ingólfsson ${ }^{6}$, \\ Kurt H. Kjær ${ }^{7}$, Thijs van Kolfschoten ${ }^{8}$, Gerhard Krinner ${ }^{9}$, Antony Long ${ }^{10}$, Juha-Pekka Lunkka ${ }^{11}$, \\ Dmitry Subetto ${ }^{12} \&$ John Inge Svendsen ${ }^{13}$ \\ 1 Department of Geology and Geochemistry, Stockholm University, Svante Arrhenius väg 8c, SE-10691 Stockholm, Sweden \\ 2 Academy of Sciences, Humanities and Literature, Mainz, Geschwister-Scholl-Str. 2, DE-55131 Mainz, and Leibniz Institute of Marine Sciences, \\ Wischhofstr. 1-3, University of Kiel, DE-24148 Kiel, Germany \\ 3 Alfred Wegener Institute for Polar and Marine Research, Bürgermeister-Smidt-Str. 20, DE-27568 Bremerhaven, Germany, and Department of \\ Geography and Geology, Øster Voldgade 10, University of Copenhagen, DK-1350 Copenhagen K, Denmark \\ 4 Greenland National Museum and Archives, Hans Egedevej 8, DK-3900 Nuuk, Greenland \\ 5 Department of Earth Sciences, Bryand Global Sciences Center, and the Climate Change Institute, University of Maine, Orono, 04469 ME, USA \\ 6 Department of Earth Sciences, University of Iceland, Askja 323, IS-101 Reykjavik, Iceland \\ 7 Natural History Museum, Øster Voldgade 5-7, University of Copenhagen, DK-1350 Copenhagen K, Denmark \\ 8 Faculty of Archaeology, Reuvensplaats 3, 2311 BE Leiden, Leiden University, the Netherlands \\ 9 National Center for Scientific Research, Laboratoire de Glaciologie et Géophysique de l'Environnement, 54 rue Molière, FR-38402 Saint Martin \\ d'Hères Cedex, France \\ 10 Department of Geography, South Road, Durham University, Durham, DH1 3LE, UK \\ 11 Institute of Geosciences, Box 3000, University of Oulu, Fl-90014 Oulu, Finland \\ 12 Department of Geography, Alexander Herzen State Pedagogical University of Russia, 6 Kazanskaya (Plekhanova), RU-191186 St. Petersburg, Russia \\ 13 Department of Earth Science, Allégaten 41, and Bjerknes Centre for Climate Research, Allégaten 55, NO-5007 Bergen, University of Bergen, \\ Norway
}

\author{
Correspondence \\ Martin Jakobsson, Department of Geology \\ and Geochemistry, Stockholm University, \\ Sweden Svante Arrhenius väg 8c, \\ SE-10691 Stockholm. E-mail: \\ martin.jakobsson@geo.su.se \\ doi:10.1111/j.1751-8369.2008.00063.x
}

The recent mass loss of the Greenland ice sheet (Chen et al. 2006), the observed increases in the velocity of its fast-flowing outlets (Luthcke et al. 2006) and the melting of the permafrost demonstrate the profound changes occurring in the Arctic region as a result of global warming (ACIA 2005). This is corroborated by systematic satellite monitoring that shows there has been a progressive decrease in the extent of sea ice over the last 30 years, with a record low in 2007 (Comiso et al. 2008). Forward modelling predicts accelerated rates of sea-ice disintegration and the almost complete disappearance of Arctic Ocean summer sea-ice cover within this century. It is clear that the environment in the Arctic is changing at a pace not previously monitored by humankind. It is equally clear, however, that to place the current changes in a millennial time perspective, we need to know more about the Pleistocene natural variability and amplitude of, for example, the Greenland ice sheet, Arctic Ocean sea ice and permafrost. Such a longer time perspective can only be established through international collaborative and multidisciplinary studies of nature's own archives, such as marine and terrestrial stratigraphic records, sediment distribution and landforms.

Studies of the palaeoenvironmental history of the Norwegian-Greenland Sea and the Arctic Ocean only took off when Holtedal (1955) studied the first sediment cores retrieved from the southern Norwegian Sea, and identified important changes in sediment composition at the transition from the Last Glacial Maximum (LGM) to the Holocene. Nansen had recovered the first Arctic sea-floor sediment samples during the voyage with the ship Fram in 1893-96, but it took another 90 years before the Swedish Ymer-80 expedition succeeded in recovering long and convincingly datable sediment cores from the deep-sea basins to the north of Svalbard (Boström \& Thiede 1984). 
The Late Cenozoic Evolution of the Polar North Atlantic Margins (PONAM, 1988-1994) and the Quaternary Environment of the Eurasian North (QUEEN, 19962002) were two European Science Foundation (ESF) programmes that aimed to decipher the palaeoenvironmental history of the Arctic region. PONAM focused on the East Greenland and Svalbard-Barents Sea margins, and QUEEN focused on northern Eurasia. These two programmes documented new evidence for major changes in the Arctic environment driven by climate change. For example, during the last glacial-interglacial cycle, ice sheets repeatedly formed during stadials over the Barents and Kara seas, and expanded into the Arctic Ocean, only to almost completely disappear during subsequent interstadials (Elverhøi et al. 1998; Svendsen et al. 2004). In contrast, PONAM concluded that the East Greenland ice sheet showed only minor fluctuations during the same time period. In four synthesis maps, QUEEN compiled extensive new observations with previous work to constrain the Eurasian maximum ice sheet limits during the Late Saalian (>140 Kya), the Early Weichselian (10080 Kya), the Middle Weichselian (60-50 Kya) and the Late Weichselian (25-15 Kya) (Svendsen et al. 2004). In a subsequent paper by Larsen et al. (2006), some modifications of the extension of the Weichselian ice sheet in Arctic Russia were suggested. The reconstructed Eurasian ice sheet limits challenged long-held views regarding the maximum dimensions of the Arctic ice sheets, and currently the QUEEN reconstructions serve as standard boundary conditions in glaciological and climatological modelling experiments involving Late Quaternary ice sheet extent. We now think that major Late Quaternary glacial events alternated with periods of higher sea levels and warmer summer temperatures, resulting in the almost total disappearance of ice sheets over Eurasia. During some of the warmer intervals, the treeline moved as far north as the shores of the Arctic Ocean, and ice-age humans colonized the Arctic region (Pavlov et al. 2001). The Yana Rhinoceros Horn Site (Yana RHS) in north-east Asia (Beringia) indicates human occupation almost 30 Kya at $71^{\circ} \mathrm{N}$ (Pitul'ko et al. 2004).

The evidence that sedimentation rates in the central Arctic Ocean were on the order of one magnitude higher than previously considered (Jakobsson et al. 2000; Backman et al. 2004) gained acceptance with the QUEEN programme. This made investigations of palaeoceanographic changes using Arctic sediment cores more promising, as higher resolution marine stratigraphies than previously anticipated could be expected. The Eurasian ice sheets did not leave traces of their build-up and decay only in central Arctic Ocean sedimentary records (Spielhagen et al. 2004). During times of extreme ice sheet growth, the marine ice sheet components also deformed the sea floor on the Siberian shelves and slopes, and ice grounding was mapped, even on the Lomonosov Ridge, at water depths down to ca. $1 \mathrm{~km}$ in the central Arctic Ocean (Jakobsson 1999; Polyak et al. 2001). The subsequent postglacial history of the shelf areas was found to be influenced by a complex relationship of sea-level rise and river run-off (Bauch et al. 2001; Stein et al. 2004).

Despite the scientific advances of the PONAM, QUEEN and other recent research programmes, our understanding of the dynamics and amplitude of extreme environmental changes over a glacial cycle in the Arctic is still incomplete. This is a major scientific challenge for the palaeoclimatic community, and was the main underlying motivation for the current network programme-Arctic Palaeoclimate and Its Extremes (APEX).

The overall scientific goal of APEX is to understand Arctic palaeoclimate changes through an interdisciplinary approach that integrates marine and terrestrial science, and utilizes modelling and field observations. APEX was formed during the QUEEN closing meeting in October 2004 in Brorfelde, Denmark. The network is now formally endorsed by the International Arctic Science Committee (IASC) and was selected by the International Polar Year (IPY) International Council for Sciences/World Meteorological Organization Joint Committee to act as one of the leading coordinating programmes for the IPY 2007-08 palaeoclimate research activities. Thirty-six IPY projects, with participants from 15 European countries, and including Russia, Canada and USA, are clustered within APEX (Table 1).

This special issue of Polar Research includes the first set of papers presenting results from APEX research. Whereas some of the field areas and scientific questions from QUEEN are addressed in further detail, APEX has broadened the area of interest from the Eurasian Arctic to include the entire circum-Arctic region. The map in Fig. 1 showing field activities was updated during the APEX Second International Conference and Workshop in April 2008. The research papers presented in this issue are based on fieldwork from the perimeter of the Kara and Laptev seas, North and East Greenland, and the central Arctic Ocean and northern North Atlantic (Fig. 1).

This special issue is dedicated to APEX Steering Committee member and dear colleague, Igor N. Demidov, who died on 16 October 2007.

\section{APEX research focus}

By "extremes", APEX targets conditions that occur at the end points of magnitude/frequency behaviour over glacial-interglacial cycles in the Arctic, such as maximum and minimum ice sheet extent, maximum and minimum 
Table 1 List of field projects included in the Arctic Palaeoclimate and Its Extremes (APEX) research network. Fieldwork locations are shown in Fig. 1.

\begin{tabular}{|c|c|c|c|}
\hline $\begin{array}{l}\text { Fieldwork area } \\
\text { in Fig. } 1\end{array}$ & $\begin{array}{l}\text { Fieldwork } \\
\text { year }\end{array}$ & Project & Contact \\
\hline 1 & 2007 & Late Glacial-Interglacial Paleoenvironment in Karelia & Dmitry Subetto subetto@mail.ru \\
\hline 2 & 2008 & Sea-level Change in the White Sea Area & \\
\hline 3 & 2009 & $\begin{array}{l}\text { Lake Records of Late Quaternary Climate Variability in Northeastern Siberia } \\
\text { (SibLake) }\end{array}$ & $\begin{array}{l}\text { Bernhard Diekmann } \\
\text { bernhard.diekmann@awi.de } \\
\text { Dmitry Subetto subetto@mail.ru }\end{array}$ \\
\hline 4 & 2007 & Arctic Natural Climate and Environmental Changes and Human Adaptation: & Eiliv Larsen eiliv.larsen@ngu.no \\
\hline 5 & 2008 & from Science to Public Awareness (SciencePub)/Subsidence, Uplift and & \\
\hline 6 & 2009 & Tilting of Traps—-the Influence on Petroleum Systems (GlaciPet) & \\
\hline 7 & 2007 & Lena-Novosibirskie Ostrova project & Alexander Makarov makarov@aari.nw.ru \\
\hline 8 & 2008 & Lena-Novosibirskie Ostrova project & \\
\hline 9 & $2009-10$ & $\begin{array}{l}\text { The South-eastern Fringe of the Eurasian Ice Sheets-Ice Sheet History and } \\
\text { Palaeoenvironmental Change in the Marginal Areas of Kara Sea-based Ice } \\
\text { Sheets During the Middle and Late Pleistocene }\end{array}$ & PerMöller per.moller@geol.lu.se \\
\hline 10 & 2007 & $\begin{array}{l}\text { Permafrost and Environmental Dynamics during Quaternary Climate } \\
\text { Variations—Studies along the Dimitrii Laptev Strait }\end{array}$ & $\begin{array}{l}\text { Lutz Schirrmeister } \\
\text { lutz.schirrmeister@awi.de }\end{array}$ \\
\hline 11 & 2008 & East Beringia 2008 & \\
\hline 12 & 2008 & $\begin{array}{l}\text { Permafrost Drilling }(<200 \mathrm{~m}) \text { in the Elgygytgyn Impact Crater. Project is } \\
\text { included in the International Continental Scientific Drilling Program (ICDP) }\end{array}$ & $\begin{array}{l}\text { Georg Schwamborn } \\
\text { georg.schwamborn@awi.de }\end{array}$ \\
\hline 13 & 2008 & Quaternary Stratigraphy of the Yamal Peninsula & Evgeny Gusev gus-evgeny@yandex.ru \\
\hline 14 & 2007 & Sea Level Changes in South Central Alaska & Natasha Barlow n.I.m.barlow@dur.ac.uk \\
\hline 15 & 2008 & & \\
\hline 16 & 2008-09 & $\begin{array}{l}\text { Glacial Depositional Environments of the Northwestern Laurentide Ice } \\
\text { Sheet, Banks Island, Canadian Arctic }\end{array}$ & $\begin{array}{l}\text { David J.A. Evans } \\
\text { d.j.a.evans@durham.ac.uk }\end{array}$ \\
\hline 17 & 2009 & Holocene Climate Change in Atlantic Canada & Paul Hughes Paul.Hughes@soton.ac.uk \\
\hline 18 & 2007 & LongTerm: Quaternary Evolution of North Greenland & $\begin{array}{l}\text { Kurt H. Kjær, Per Möller kurtk@snm.ku.dk } \\
\text { per.moller@geol.lu.se }\end{array}$ \\
\hline 19 & 2008 & Response of the Inland Ice-sheet to Natural Climate Changes (RINK) & Kurt H. Kjær kurtk@snm.ku.dk \\
\hline 20 & 2009 & & \\
\hline 21 & 2007 & Sea-level Changes in South Greenland & $\begin{array}{l}\text { Antony Long, Sarah Woodroffe, Leanne } \\
\text { Wake a.j.long@durham.ac.uk }\end{array}$ \\
\hline 22 & 2008 & & $\begin{array}{l}\text { s.a.woodroffe@durham.ac.uk } \\
\text { I.m.wake@durham.ac.uk }\end{array}$ \\
\hline 23 & 2009 & $\begin{array}{l}\text { Marine Geophysical and Geological Investigation of Past Flow and Stability } \\
\text { of a Major Greenland Ice Stream in the Late Quaternary }\end{array}$ & $\begin{array}{l}\text { Colm O'Cofaigh } \\
\text { colm.o'cofaigh@durham.ac.uk }\end{array}$ \\
\hline 24 & 2008 & $\begin{array}{l}\text { Polar Climate Stability Network-Canada-Northern Baffin Bay Expedition on } \\
\text { the Hudson }\end{array}$ & $\begin{array}{l}\text { Claude Hillaire-Marcel, Anne de Vernal } \\
\text { chm@uqam.ca } \\
\text { devernal.anne@uqam.ca }\end{array}$ \\
\hline 25 & 2007 & SciencePub: Ice-sheet-Ocean Interaction & Jon Landvik jon.landvik@umb.no \\
\hline 26 & 2008 & & \\
\hline 27 & 2009 & & \\
\hline 28 & 2008 & Re-evaluating the Late Quaternary Stratigraphy of Svalbard & Ólafur Ingólfsson oi@hi.is \\
\hline 29 & 2009 & & \\
\hline 30 & 2008 & Paleocene Cooling on Svalbard & $\begin{array}{l}\text { Robert F. Spielhagen } \\
\text { rspielhagen@ifm-geomar.de }\end{array}$ \\
\hline 31 & 2007 & Arctic-2007 cruise onboard Academic Fedorov & Evgeny Gusev gus-evgeny@yandex.ru \\
\hline 32 & 2007 & Glacial Geomorphology of East Myrdalsjokull, Southern Iceland & $\begin{array}{l}\text { David J.A. Evans } \\
\text { d.j.a.evans@durham.ac.uk }\end{array}$ \\
\hline 33 & 2008 & Glacial Geomorphology of Heinabergsjokull, Southern Iceland & $\begin{array}{l}\text { David J.A. Evans } \\
\text { d.j.a.evans@durham.ac.uk }\end{array}$ \\
\hline 34 & 2007 & $\begin{array}{l}\text { Vatnajökull Meltwater Discharge Variability_an Unexplored Holocene } \\
\text { Climate Sensor in the Nordic Sea Region }\end{array}$ & Ólafur Ingólfsson oi@hi.is \\
\hline 35 & 2007 & $\begin{array}{l}\text { Lomonosov Ridge off Greenland (LOMROG): Marine Geophysical Mapping } \\
\text { and Coring of the Lomonosov Ridge and Morris Jesup Rise North of } \\
\text { Greenland with Icebreaker Oden }\end{array}$ & $\begin{array}{l}\text { Martin Jakobsson } \\
\text { martin.jakobsson@geo.su.se }\end{array}$ \\
\hline 36 & 2007-08 & $\begin{array}{l}\text { Past Climate Extremes in the North (PACE): Onset and Decay of Last Cold } \\
\text { Stage in North-western Russia }\end{array}$ & $\begin{array}{l}\text { Juha Pekka Lunkka } \\
\text { juha.pekka.lunkka@oulu.fi }\end{array}$ \\
\hline
\end{tabular}


Table 1 continued

\begin{tabular}{|c|c|c|c|}
\hline $\begin{array}{l}\text { Fieldwork area } \\
\text { in Fig. } 1\end{array}$ & $\begin{array}{l}\text { Fieldwork } \\
\text { year }\end{array}$ & Project & Contact \\
\hline 37 & 2007 & SciencePub/Arctic Ocean Warming in the Past (WARMPAST): marine & Katrine Husum \\
\hline 38 & 2008 & geological cruises with RV Jan Mayen & katrine.husum@ig.uit.no \\
\hline 39 & 2009 & & \\
\hline 40 & 2007 & RV Polarstern cruise ARK-XXII/2 & Robert F. Spielhagen \\
\hline 41 & 2007 & $\begin{array}{l}\text { Holocene Variability in the Arctic Gateway: RV M.S. Merian cruise } \\
\text { MSM05/5b }\end{array}$ & rspielhagen@ifm-geomar.de \\
\hline 42 & & $\begin{array}{l}\text { Polygons in Tundra Wetlands: Dynamics and Response to Climate Variability } \\
\text { in Polar Regions (POLYGON) }\end{array}$ & $\begin{array}{l}\text { Lutz Schirrmeister } \\
\text { lutz.schirrmeister@awi.de }\end{array}$ \\
\hline
\end{tabular}

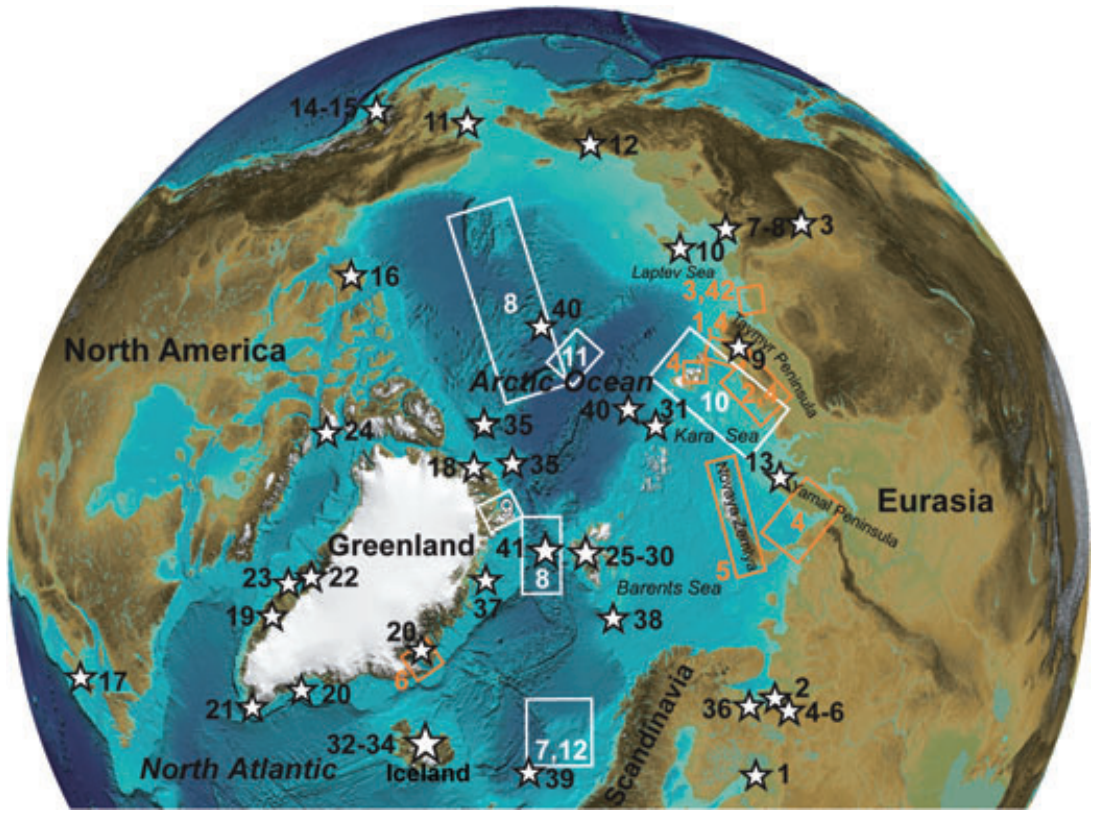

Fig. 1 Map of field projects included in the Arctic Palaeoclimate and Its Extremes (APEX) research network. The map was constructed during APEX's Second International Conference and Workshop. Stars indicate fieldwork locations, both for planned work and work already conducted. For project names and other details, see Table 1. The areas in focus in this special issue are marked with orange (terrestrial) and white (marine) boxes: 1 , Möller et al.; 2, Hjort \& Funder; 3, Schirrmeister et al.; 4, Ingólfsson et al.; 5, Mangerud et al.; 6, Hall et al.; 7, Bauch et al.; 8, Darby \& Zimmerman; 9, NørgaardPedersen et al.; 10, Polyak et al.; 11, Löwemark et al.; 12, Van Nieuwenhove et al. air temperatures, or rapid changes in oceanography and sea ice. Importantly, it must be recognized that to define an "extreme" we need a robust understanding of the background, or "steady state", of a particular system. This can be achieved for past Arctic climate and environmental conditions through studies of the landforms of the Arctic, glaciers and ice sheets, and sediments deposited on land and in the ocean. These archives comprise the available source data to decipher key components of the palaeoclimatic and palaeoenvironmental evolution of the Arctic region, and, thus, to potentially define extreme conditions. However, only by integrating the results from terrestrial and marine studies will it be possible to develop a holistic understanding of the role of the Arctic in the global climate system. The APEX programme is coordinated around the following six research themes.

- Cold extremes: Arctic marine and terrestrial glacial maxima; sea-level minima and sea-ice maxima; Arctic
Ocean palaeoceanography; ice shelf extent; past atmospheric circulation.

- Warm extremes: interglacial and interstadial environments; sea level maxima; sea-ice minima; Arctic Ocean palaeoceanography; ice shelf extent.

- Hydrological extremes: fluvial-marine interaction; freshwater budget and ice-dammed lakes.

- Permafrost extremes: maximum and minimum extent; rates of change; response to climate change.

- Glaciodynamical extremes: ice sheet configurations and instability; palaeo-ice-stream dynamics and feedback mechanisms.

- Biotic change: evolution of the Arctic marine and terrestrial biosphere, and its response to extreme palaeoclimatic conditions; ice-age development of human settlement.

- Human adaptation to environmental and climate extremes. 


\section{Summary of the first results from APEX presented in this issue}

\section{Terrestrial data}

The Late Quaternary Eurasian ice sheet reconstructions by the QUEEN programme (Svendsen et al. 2004) are central to the ongoing APEX research in the Eurasian Arctic (Fig. 1). In some areas, modifications of the ice sheet limits published by Svendsen et al. (2004) have been suggested (e.g., Larsen et al. 2006), whereas in other areas there seems to be a larger consensus on the ice sheet extent in time and space. This is how research progresses, and as more fieldwork is carried out within APEX we will see more updates. However, it is hard to envision a paradigm shift comparable with the change of the long-held view of the existence of a huge circumArctic Late Weichselian ice sheet (Grosswald 1998).

In this issue of Polar Research, Astakhov discusses the ice sheet reconstructions of QUEEN in a climatic context. There are clear patterns in spatial extent during the different Weichselian maximum extentions, in particular along an east-west profile. Whereas the Early Weichselian Scandinavian ice sheet to the west was relatively small, the ice sheet over the Barents-Kara seas and Arctic Russian mainland to the east was large. In contrast, during the Late Weichselian the ice sheet was large over Scandinavia, the adjacent north-western Europe and Svalbard-Barents Sea, whereas it was relatively limited over Arctic Russia, and did not reach the eastern fringe of the Kara Sea region. Astakhov suggests that this pattern of ice sheet asymmetry can be explained by a progressive aridification of the Eurasian north during the Late Quaternary. The climate of eastern Eurasia during the last glaciation was characterized by extreme cold and dry conditions. As moisture is the key factor to grow an ice sheet, the progressive dryness and lack of moisture supply from the North Atlantic inhibited the growth of a significant Late Weichselian ice sheet in western Siberia. The overarching climatic mechanism leading to this aridification is, however, not understood, and more research is required. This scientific question is a challenge for APEX, and may inspire the network's numerical modellers.

The Taymyr Peninsula is the northernmost part of the Eurasian continent that was reached by Late Quaternary ice sheets. Möller et al. (this issue) investigated the northwesternmost tip of Taymyr, called Cape Chelyuskin. They conclude that the Eurasian LGM ice sheet did not reach the northern Taymyr Peninsula. The two glaciations that they identified to have extended over this area were the Saalian (marine isotope stage 6 [MIS 6]) glaciation and Early Weichselian (MIS 5.4) glaciation. Based on fieldwork results from further to the south on the western
Taymyr Peninsula, Hjort $\&$ Funder (this issue) discuss the problem of glacial inception, i.e., how the first ice sheets begin to form and grow. They interpret their data to show that glaciers in the Byrranga Mountains and nearby highlands during at least two occasions began to grow and later expanded towards the coast, to eventually merge with larger ice sheets. However, the younger of the glacial inceptions in the Byrranga Mountain area is presumed to be of Saalian age by Hjort $\&$ Funder, and the last event when a large ice sheet from the Kara Sea basin covered the southern Taymyr Peninsula occurred during the Early or Middle Weichselian. Furthermore, they conclude that southern Taymyr was ice-free during the LGM, in agreement with the QUEEN reconstruction of Svendsen et al. (2004).

Ice sheet inception is a topic that is further discussed by Ingólfsson et al. in this APEX special issue. From analyses of stratigraphies from the perimeter of the Kara Sea, and the pattern of very high raised beaches on Severnaya Zemlya, they find support for the inception model developed by Siegert et al. (2002), which in turn, was inspired by ideas from, e.g., Hughes et al. (1977). The theory is that mountainous areas around the Kara Sea basin, as well as islands with existing ice caps, act as breeding spots for glaciers that, when the climate develops towards the glacial stage mode, eventually grow large and thick enough to cause substantial isostatic depression. The isostatic depression of the perimeter of the Kara Sea basin causes an uplift of the shallow shelf area as a result of forebulging. The net effect from this, and a global drop in sea levels caused by the growing large ice sheets in the Northern hemisphere, is an overall shallower Kara Sea. The shallower Kara Sea facilitates the formation of thick perennial sea ice, which ultimately turns into grounded shelf ice in some areas. Once glaciers from the surrounding coastal areas and islands merge with the shelf ice, the Kara Sea marine-based ice sheet develops.

From the western Laptev Sea east of the Taymyr Peninsula all the way to Alaska, a huge landmass repeatedly formed when the sea level was lower during glacial periods. This large, extremely low-relief, landmass is commonly referred to as Beringia, and the current consensus is that no large ice sheets existed there during the Late Quaternary because of the extremely dry environment. The coastal areas of eastern Siberia, which during glacial periods comprised the inland continuation of Beringia, are characterized by thick permafrost that formed because of the cold and dry climate. Permafrost contains frozen sediment sequences and ground ice that comprise excellent palaeoenvironmental archives. Schirrmeister et al. (this issue) have extracted palaeo-information about the landscape evolution and climate during the last $60 \mathrm{Ky}$ from such exposed permafrost sections along the 
western Laptev Sea coast. Schirrmeister et al. conclude that the LGM period was characterized by very cold and dry climate conditions, thereby supporting the suggestion that not enough moisture reached eastern Siberia to extend the Late Weichselian ice sheet over the Taymyr Peninsula.

Not all parts of the Russian Arctic have been accessible for fieldwork, even since the end of the Cold War. One of the most restricted areas is the archipelago of Novaya Zemlya bordering the Barents and Kara seas. In these cases, material collected during earlier expeditions may be extremely valuable, provided that proper metadata exist and samples have been curated properly. Mangerud et al. (this issue) analysed mollusc shells collected in 1921 during an expedition to Novaya Zemlya led by the Norwegian geologist O. Holtedahl. Through radiocarbon and amino acid racemization dating of the mollusc shells, Mangerud et al. are able to conclude that Novaya Zemlya was ice-free at $35-27{ }^{14} \mathrm{C}$ Kya. By further analyses of the amino acid racemization results they find that the Late Weichselian ice sheet only overrode the island during the later part of its existence, possibly even following the LGM.

The last of the terrestrial papers in this special APEX issue addresses the most extensive glacial advances that have occurred during the Holocene in the Stauning Alper, located in the Scoresby Sund region of East Greenland. Hall et al. (this issue) find that the maximum Holocene ice extent in this area occurred during the Little Ice Age.

\section{Marine data}

Ongoing environmental changes in the Arctic make the analysis of past warm extremes a key issue for research within APEX. It has been suggested that the present warming in the Arctic might lead to similar environmental conditions as those prevailing during the last interglacial stage, the Eemian (MIS5e) (Brigham-Grette \& Hopkins 1995), that lasted from ca. 132000 to 116000 years B.P. (132-116 Kya) (Shackleton et al. 2003). It should be noted that the base of MIS5e appears to be some 6000 years older than the start of the Eemian Interglacial, which also seems to end well into MIS5d, after the characteristic 5e plateau in benthic $\delta^{18} \mathrm{O}$ (Shackleton et al. 2003). Recent Eemian Arctic palaeoclimate data (Anderson et al. 2006) and modelling efforts (Otto-Bliesner et al. 2005) suggest a warmer Arctic than at present, including a strongly reduced sea-ice coverage. As many last interglacial deposits in the Arctic can hardly be dated more accurately than generally assigning an "Eemian" age to them, it is particularly important to determine the exact timing and modes of oceanic heat flux to the Arctic, which largely occurs by the advection of Atlantic Water from the North Atlantic. In this issue, the papers of Bauch $\&$ Erlenkeuser and Van Nieuwenhove et al. deal with this problem using two widely distributed microfossil groups, which allow semiquantitative reconstructions of water temperatures in the Norwegian Sea during the Eemian period. In contrast with the present interglacial period (last $12 \mathrm{Ky}$ ), when an insolation maximum at $65^{\circ} \mathrm{N}$ around 10 Kya resulted in an early Holocene thermal maximum in the Arctic (Kaufman et al. 2004), Bauch $\delta$ Erlenkeuser and Van Nieuwenhove et al. show clear evidence of a late Eemian age for the period of warmest near-surface temperatures in the Norwegian Sea. At that time (around $117 \mathrm{Kya}$ ), July insolation at $65^{\circ} \mathrm{N}$ had already decreased to ca. $85 \%$ of its interglacial maximum reached at around $126 \mathrm{Kya}$. As the authors of both papers also find indications of fresher surface waters in the early Eemian, they attribute the apparent delay of fully marine interglacial conditions (i.e., an offset in timing between peak insolation and peak warming) to the melting of the huge Saalian ice sheet over northern Eurasia. Through the release of meltwater, this ice sheet may have exerted an influence on water masses in the northern North Atlantic for a significantly longer time interval than did the (smaller) LGM ice sheet during the last deglaciation and early Holocene.

The Late Quaternary ice sheets on northern Eurasia were a major research topic of the ESF QUEEN programme, and represent a cold extreme end member of palaeoclimate variability, as has also been investigated by APEX. The ice sheet extent in the north-eastern Kara Sea, however, was an open question in the synthesis of the QUEEN results. In this issue, Polyak et al. present new shallow seismic data from this area, and interpret the pre-Holocene sea floor deposits as a diamicton, which apparently extends close to the Taymyr Penisula of northernmost Siberia. These results and the findings of basin infilling sediments south of the southern ice margin on the shelf are in support of a short-term ice sheet advance across the north-eastern Kara Sea, and may help to close an important gap of knowledge regarding the Eurasian ice sheet history.

Both terrestrial and marine results from QUEEN revealed an ice sheet variability on time scales of only 5-10 Ky for build-up and decay during the Weichselian (Spielhagen et al. 2004; Svendsen et al. 2004; Larsen et al. 2006), but resolution of the marine sediment cores was too low to identify short-term events. On the opposite side of the Arctic Ocean, the situation is somewhat different. Little is known from terrestrial records about ice sheet variability in northernmost North America prior to the LGM. From the analysis of sand-sized mineral grains in marine ice-rafted Arctic sediments, however, Darby $\&$ Zimmerman (this issue) could reconstruct a short-term 
variability of the two major ice sheets in this area, the Innuitian and Laurentide ice sheets. According to their findings, partial ice sheet collapses and rebuilding occurred within $<5 \mathrm{Ky}$, and thus on time scales of the North Atlantic Heinrich events. It remains a matter of future research within APEX to find out what triggered these short-term surge events in the relatively dry glacial climates of the North American Arctic.

The deglacial history of Independence Fjord and the adjacent Wandel Sea Basin in northermost Greenland may be representative of large portions of the Canadian Islands and North Greenland along the Arctic continental margin. In this issue, Nørgaard-Pedersen et al. present first, and to a large extent still preliminary, results from this previously unexplored area. Their findings of a subglacial till suggest that the Greenland ice sheet extended far out onto the North Greenland shelf during the LGM. The presence of benthic and planktic foraminifers in Early Holocene marine deposits overlying the till indicates that Atlantic subsurface waters may have intruded into the fjord system shortly after the deglaciation. Such findings fit well in the accumulating evidence for a relatively strong Atlantic Water inflow through Fram Strait in the early Holocene, as was also noted at other sites around north-east Greenland.

The sixth paper dealing with marine sediments in this issue elaborates on the detection of palaeoceanographic signals in sediment cores by the use of X-ray fluoresence core-scanning methods. Löwemark et al. show that advanced instruments are able to trace a short-term variability of bottom water ventilation in the Arctic Ocean through the measurement of Manganese content in sediment cores. Such non-destructive logging methods are becoming ever more important in palaeoceanographic research, because they can be performed at a resolution that is only rarely achieved by conventional sample analyses. The results of Löwemark et al. update the earlier work of Jakobsson et al. (2000), and demonstrate in more detail that deepwater environments in the Arctic Ocean underwent similar rapid changes as did surface waters. To reveal the various parameters that control the variability of deepwater ventilation and renewal, and its exchange with the world ocean, will be a matter of future research within APEX.

\section{Acknowledgements}

APEX was endorsed by IASC in 2008. The First International Conference and Workshop, held during 28-30 March 2007 at the Royal Swedish Academy of Sciences, Stockholm, was supported by the ESF European Polar Board and the Bert Bolin Centre for Climate Research, Stockholm University. The Second International Confer- ence and Workshop, which took place from 1 to 4 April 2008 at the Department of Geography, Durham University, UK, was supported by IASC and Durham University.

\section{References}

ACIA (Arctic Climate Impact Assessment) 2005. Arctic Climate Impact Assessment-scientific report. Cambridge: Cambridge University Press.

Anderson P., Bennike O., Bigelow N., Brigham-Grette J., Duvall M., Edwards M., Frechette B., Funder S., Johnsen S., Knies J., Koerner R., Lozhkin A., Marshall S., Matthiessen J., Macdonald G., Miller G., Montoya M., Muhs D., Otto-Bliesner B., Overpeck J., Reeh N., Sejrup H.P., Spielhagen R., Turner C. \& Velichko A. 2006. Last interglacial Arctic warmth confirms polar amplification of climate change. Quaternary Science Reviews 25, 1383-1400.

Backman J., Jakobsson M., Løvlie R., Polyak L. \& Febo L.A. 2004. Is the central Arctic Ocean a sediment starved basin? Quaternary Science Reviews 23, 1435-1454.

Bauch H.A., Mueller-Lupp T., Taldenkova E., Spielhagen R.F., Kassens H., Grootes P.M., Thiede J., Heinemeier J. \& Petryashov V.V. 2001. Chronology of the Holocene transgression at the north Siberian margin. Global and Planetary Change 31, 125-139.

Boström K. \& Thiede J. 1984. Ymer-80 Swedish Arctic Expedition. Cruise report for marine geology and geophysics. Meddelanden från Stockholms Universitets Geologiska Institution 260.

Brigham-Grette J. \& Hopkins D. 1995. Emergent marine record and paleoclimate of the last interglaciation along the northwest Alaskan coast. Quaternary Research 43, 159-173.

Chen J.L., Wilson C.R. \& Tapley B.D. 2006. Satellite gravity measurements confirm accelerated melting of Greenland ice sheet. Science 313, 1958-1960.

Comiso J.C., Parkinson C.L., Gersten R. \& Stock L. 2008. Accelerated decline in the Arctic sea ice cover. Geophysical Research Letters 35, 1-6.

Elverhøi A., Dowdeswell J.A., Funder S., Mangerud J. \& Stein R. 1998. Glacial and oceanic history of the polar North Atlantic margins: an overview. Quaternary Science Reviews 17, 1-10.

Grosswald M.G. 1998. Late Weichselian ice sheets in Arctic and Pacific Siberia. Quaternary International 45/46, 3-18.

Holtedal H. 1955. On the Norwegian continental terrace, primarily outside Möre-Romsdal: its geomorphology and sediments. Bergen: University of Bergen.

Hughes T.J., Denton G.H. \& Grosswald M.G. 1977. Was there a late-Würm Arctic ice sheet? Nature 266, 596-602.

Jakobsson M. 1999. First high-resolution chirp sonar profiles from the central Arctic Ocean reveal erosion of Lomonsov Ridge sediments. Marine Geology 158, 111-123.

Jakobsson M., Løvlie R., Al-Hanbali H., Arnold E., Backman J. \& Mörth M. 2000. Manganese and color cycles in Arctic 
Ocean sediments constrain Pleistocene chronology. Geology $28,23-26$.

Kaufman D.S., Ager T.A., Anderson N.J., Anderson P.M., Andrews J.T., Bartlein P.J., Brubaker L.B., Coats L.L., Cwynar L.C., Duvall M.L., Dyke A.S., Edwards M.E., Eisner W.R., Gajewski K., Geirsdóttir A., Hu F.S., Jennings A.E., Kaplan M.R., Kerwin M.W., Lozhkin A.V., MacDonald G.M., Miller G.H., Mock C.J., Oswald W.W., Otto-Bliesner B.L., Porinchu D.F., Ruhland K., Smol J.P., Steig E.J. \& Wolfe B.B. 2004. Holocene thermal maximum in the western Arctic $\left(0-180^{\circ} \mathrm{W}\right)$. Quaternary Science Reviews 23, 529-560.

Larsen E., Kjær K.H., Demidov I.N., Funder S., Grøsfjeld K., Houmark-Nielsen M., Jensen M., Linge H. \& Lyså A. 2006. Late Pleistocene glacial and lake history of northwestern Russia. Boreas 35, 394-424.

Luthcke S.B., Zwally H.J., Abdalati W., Rowlands D.D., Ray R.D., Nerem R.S., Lemoine F.G., McCarthy J.J. \& Chinn D.S. 2006. Recent Greenland ice mass loss by drainage system from satellite gravity observations. Science 314, 1286-1289.

Otto-Bliesner B.L., Marshall S.J., Overpeck J.T., Miller G.H. \& Hu A.X. 2005. Simulating Arctic climate warmth and icefield retreat in the last interglaciation. Science 311, 1751-1753.

Pavlov P., Svendsen J.I. \& Indrelid S. 2001. Human presence in the European Arctic nearly 40,000 years ago. Nature 413, 64-67.

Pitul'ko V.V., Nikolsky P.A., Girya E.Y., Basilyan A.E., Tumskoy V.E., Koulakov S.A., Atsakhov S.N., Pavlova E.Y. \& Anisimov M.A. 2004. The Yana RHS site: humans in the
Arctic before the Last Glacial Maximum. Science 303, 52-56.

Polyak L., Edwards M.H., Coakley B.J. \& Jakobsson M. 2001. Ice shelves in the Pleistocene Arctic Ocean inferred from glaciogenic deep-sea bedforms. Nature 410, 453-459.

Shackleton N.J., Sánchez-Goni M.F., Pailler D. \& Lancelot Y. 2003. Marine isotope substage 5e and the Eemian interglacial. Global and Planetary Change 36, 151-155.

Siegert M.J., Dowdeswell J.A., Svendsen J.-I. \& Elverhøi A. 2002. The Eurasian Arctic during the last ice age. American Scientist 90, 32-39.

Spielhagen R.F., Baumann K.H., Erlenkeuser H., Nowaczyk N.R., Nørgaard-Pedersen N., Vogt C. \& Weiel D. 2004. Arctic Ocean deep-sea record of northern Eurasian ice sheet history. Quaternary Science Reviews 23, 1455-1483.

Stein R., Dittmers K., Fahl K., Kraus M., Matthiessen J., Niessen F., Pirrung M., Polyakova Y., Schoster F., Steinke T. \& Fütterer D.K. 2004. Arctic (palaeo) river discharge and environmental change: evidence from the Holocene Kara Sea sedimentary record. Quaternary Science Reviews 23, 1485-1511.

Svendsen J.I., Alexanderson H., Astakhov V.I., Demidov I., Dowdeswell J.A., Henriksen M., Hjort C., Houmark-Nielsen M., Hubberten H.W., Ingólfsson O., Jakobsson M., Kjær K., Larsen E., Lokrantz H., Lunkka J.P., Lyså A., Mangerud J., Maslenikova O., Matioushkov A., Murray A., Möller P., Niessen F., Saarnisto M., Siegert C., Stein R., Siegert M.J. \& Spielhagen R. 2004. The late Quaternary ice sheet history of northern Eurasia. Quaternary Science Reviews 23, 1229-1271. 